\title{
Vascular Endothelial Growth Factor D
}

National Cancer Institute

\section{Source}

National Cancer Institute. Vascular Endothelial Growth Factor D. NCI Thesaurus. Code C104387.

Vascular endothelial growth factor D (354 aa, $40 \mathrm{kDa}$ ) is encoded by the human VEGFD gene. This protein plays a role in angiogenesis, lymphangiogenesis, and endothelial cell growth, and also has effects on the permeability of blood vessels. 